\title{
Bronchogenic cyst in left anterior cranial fossa
}

Figure 1 Head CT and MRI
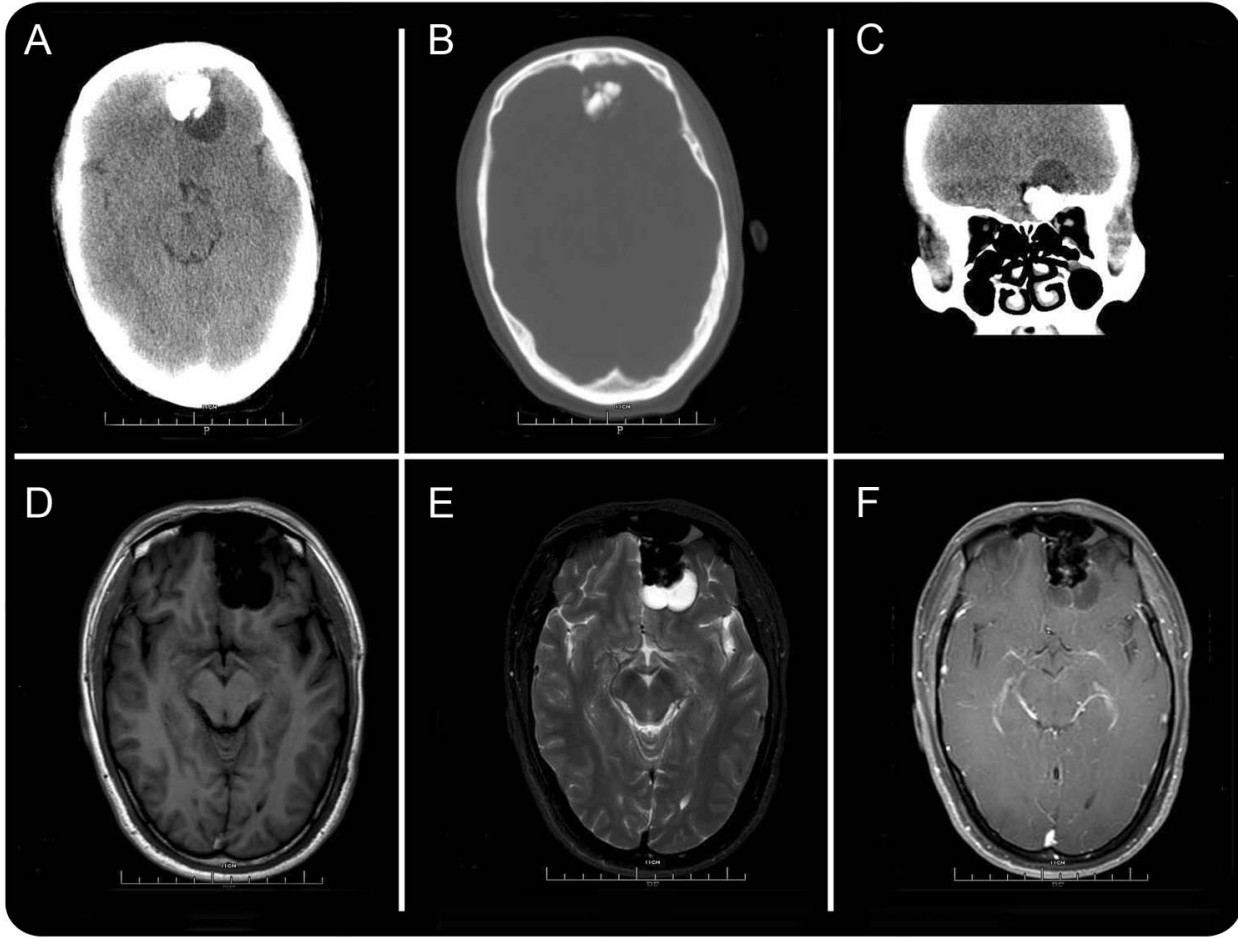

(A, B) The mass in the left anterior cranial fossa with calcification and cystic degeneration. (C) The mass was closely related to ethmoid sinus. (D) (T1-weighted) and (E) (T2-weighted): The mass was irregularly shaped with signals that indicated calcification and cystic degeneration. (F) Slightly marginal enhancement on gadolinium enhancement.

A 33-year-old man had dizziness for 3 days without provoking factors. Head CT demonstrated a mass in the left lateral anterior cranial fossa with calcification and cystic degeneration (figure 1, A-C). MRI showed an irregularly shaped mass with mixed signal and slight marginal enhancement (figure 1, D-F). He underwent mass resection with no recurrent dizziness during 12 months' follow-up. On pathologic examination, the cyst inner lining consisted of ciliated pseudostratified columnar epithelium ${ }^{1,2}$ (figure 2). The diagnosis was bronchogenic cyst, a rare congenital malformation of ventral foregut development. Surgical excision is the elective treatment.

\section{Qingsheng Xu, MD, Yiping Feng, $M D$, Ke Ye, MD, Yongqing Zhou, MD, Renya Zhan, PhD}

From the First Affiliated Hospital, College of Medicine, Zhejiang University, Hangzhou, Zhejiang Province, PR China.

Author contributions: All authors participated in the study concept and design and figure acquisition. Dr. Xu, Dr. Feng, and Dr. Zhou drafted the manuscript. Dr. Ye provided pathologic input. Dr. Zhan revised the manuscript. All authors made an intellectual contribution to the final manuscript.

Study funding: No targeted funding reported.

Disclosure: The authors report no disclosures relevant to the manuscript. Go to Neurology.org for full disclosures.

Correspondence to Dr. Zhan: qsxu10@126.com 


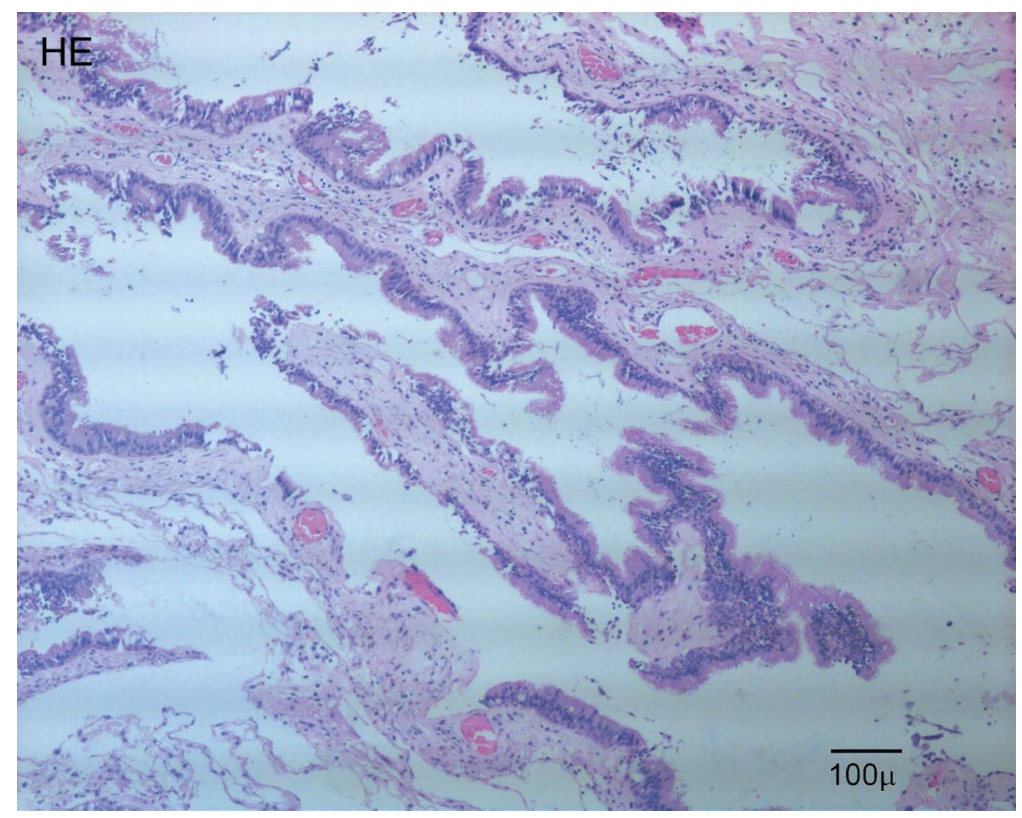

Hematoxylin \& eosin staining $(\times 200)$ demonstrates that the walls of the excised cysts were lined with pseudostratified ciliated columnar epithelium and the underlying smooth muscle components of the cysts.

1. Stubenvol F, Beschorner R, Danz S, Freudenstein D. Fronto-laterally located supratentorial bronchogenic cyst: case report and review of the literature. Clin Neuropathol 2006;25:123-127.

2. Wang J, Guo Z, Wang Y, Qiu B, Xing D. Microsurgical management of bronchogenic cysts in the thalamus: an illustrative case and literature review. Br J Neurosurg 2014;28:516-519.

\section{Introducing Stackly}

Organize. Disseminate. Collaborate. Discover.

\section{经stackly}

With simple tools for collecting, organizing, and sharing research materials, Stackly is the new center of your research world.

- Share what you find and discover what others share

- Collaborate with colleagues on topics that matter to you most

Stackly will integrate with your web browser and work directly with all Neurology ${ }^{\circledR}$ Journals as well as other publication sites. Access Stackly on the home page and to the right of each article. Visit http://www.neurology.org/site/includefiles/homepage/stackly.xhtml to learn more and start stacking for FREE. 


\title{
Neurology
}

\author{
Bronchogenic cyst in left anterior cranial fossa \\ Qingsheng Xu, Yiping Feng, Ke Ye, et al. \\ Neurology 2015;84;1181-1182 \\ DOI 10.1212/WNL.0000000000001368
}

\section{This information is current as of March 16, 2015}

\section{Updated Information \& Services}

References

Subspecialty Collections

Permissions \& Licensing

Reprints including high resolution figures, can be found at: http://n.neurology.org/content/84/11/1181.full

This article cites 2 articles, 0 of which you can access for free at: http://n.neurology.org/content/84/11/1181.full\#ref-list-1

This article, along with others on similar topics, appears in the following collection(s):

All Clinical Neurology

http://n.neurology.org/cgi/collection/all_clinical_neurology All Cognitive Disorders/Dementia

http://n.neurology.org/cgi/collection/all_cognitive_disorders_dementia All Oncology

http://n.neurology.org/cgi/collection/all_oncology

\section{CT}

http://n.neurology.org/cgi/collection/ct

MRI

http://n.neurology.org/cgi/collection/mri

Information about reproducing this article in parts (figures,tables) or in its entirety can be found online at:

http://www.neurology.org/about/about_the_journal\#permissions

Information about ordering reprints can be found online:

http://n.neurology.org/subscribers/advertise

Neurology ${ }^{\circledR}$ is the official journal of the American Academy of Neurology. Published continuously since 1951, it is now a weekly with 48 issues per year. Copyright @ 2015 American Academy of Neurology. All rights reserved. Print ISSN: 0028-3878. Online ISSN: 1526-632X.

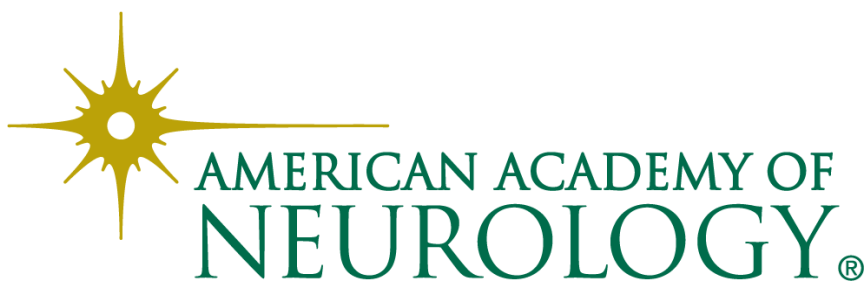

